\title{
Recovery Slime Waste from Feldspar Flotation Plant at Attanee International Co. Ltd., Tak Province, Thailand
}

\author{
Natatsawas Soonthornwiphat ${ }^{*}$, Somsak Saisinchai, and Pornthip Parinayok \\ Department of Mining and Petroleum Engineering, Faculty of Engineering, Chulalongkorn University, \\ Bangkok, 10330, Thailand \\ E-mail: *natatsawas.s@hotmail.com (Corresponding author)
}

\begin{abstract}
The purpose of this research is to recover slime waste from feldspar flotation plant at Attanee International Co., Ltd., Tak province. Slime waste with particle size less than 230 mesh, is found about $20 \%$ of the total ore feed. Since 1985 , company has been producing slime waste approximately 200,000 tons, causing a huge pile of stock and obstructing the operation area. The mineral compositions of slime waste by X-Ray Diffraction (XRD) showed that it consisted of albite, orthoclase, quartz, and ferrous impurity minerals such as muscovite, biotite, mica, and garnet. The elemental analysis by X-Ray Fluorescent (XRF) showed that the percentage of grade contained $72.53 \% \mathrm{SiO}_{2}, 15.70 \% \mathrm{Al}_{2} \mathrm{O}_{3}, 1.56 \% \mathrm{Fe}_{2} \mathrm{O}_{3}, 0.16 \% \mathrm{TiO}_{2}, 0.40 \% \mathrm{CaO}, 0.07 \% \mathrm{MgO}$, $4.87 \% \mathrm{~K}_{2} \mathrm{O}$ and $4.38 \% \mathrm{Na}_{2} \mathrm{O}$. After that, this slime waste was sent to the processes of dirt washing, classifying, attrition scrubbing, separating the ferrous impurity minerals, and preparing for flotation by washing drum, trommel, attrition scrubber, cone classifier, permanent drum magnetic separator, wet high intensity magnetic separator, and hydrocyclone. At this stage, the slime mainly consisted of albite, orthoclase, and quartz with $74.43 \% \mathrm{SiO}_{2}, 15.15 \% \mathrm{Al}_{2} \mathrm{O}_{3}, 0.12 \%$ $\mathrm{Fe}_{2} \mathrm{O}_{3}, 0.04 \% \mathrm{TiO}_{2}, 0.43 \% \mathrm{CaO}, 0.01 \% \mathrm{MgO}, 4.73 \% \mathrm{~K}_{2} \mathrm{O}$ and $4.75 \% \mathrm{Na}_{2} \mathrm{O}$ at a yield $35 \%$. Study on fine feldspar flotation, which is for removing quartz from feldspar, showed that the optimum condition of $20 \%$ solids must be adjusted to $\mathrm{pH} 2$ by hydrofluoric acid (HF), using ATD as a collector at 1,400 grams per ton feed, conditioning time and flotation time of 5 minutes each. The results of the study showed that the recovery of feldspar attained $69.7 \%$ with $67.82 \%$ $\mathrm{SiO}_{2}, 18.54 \% \mathrm{Al}_{2} \mathrm{O}_{3}, 0.14 \% \mathrm{Fe}_{2} \mathrm{O}_{3}, 0.03 \% \mathrm{TiO}_{2}, 0.52 \% \mathrm{CaO}, 0.006 \% \mathrm{MgO}, 6.88 \% \mathrm{~K}_{2} \mathrm{O}$ and $6.07 \% \mathrm{Na}_{2} \mathrm{O}$, which meet ceramic industry's specifications.
\end{abstract}

Keywords: Feldspar, slime waste, flotation, quartz, recovery.

ENGINEERING JOURNAL Volume 20 Issue 4

Received 3 March 2016

Accepted 13 June 2016

Published 1 August 2016

Online at http://www.engj.org/

DOI:10.4186/ej.2016.20.4.69 


\section{Introduction}

Feldspar is an important raw material for ceramic, glass, pottery, plastics, rubber, paint, electrical wire and glazing industries. The demand of feldspar has been continuously increased particularly on ceramic and glass industries due to its alumina and alkaline contents. Feldspar, a fluxing agent and glass matrix, does not only enhance the transparency of products, but also reduces the melting temperature. As a result, the energy consumption during ceramic and glass manufacturing can be reduced by using feldspar $[1,2]$.

Feldspar is generally found under a large variety of geological conditions which is more widespread than other mineral group in the earth crust. The mineralogical composition of feldspar minerals can be expressed in terms of the ternary system: albite is sodium rich feldspar, having an empirical formula of $\mathrm{NaAlSi}_{3} \mathrm{O}_{8}$, orthoclase and anorthite are potassium and calcium rich feldspar which are having an empirical formula $\mathrm{KAlSi}_{3} \mathrm{O}_{8}$ and $\mathrm{CaAl}_{2} \mathrm{Si}_{2} \mathrm{O}_{8}$ respectively. Chemically, feldspar is a group of aluminosilicate minerals containing sodium, iron, titanium, potassium, calcium, magnesium or the combination of these elements [3, 4].

In Thailand, feldspar deposits can be found in many provinces such as Tak, Nakhonsithammarat, Ratchaburi, Kanchanaburi, Uthaithani, Chiangmai, Lumphun and Sukothai. Attanee International Co., Ltd. is one of feldspar producers in Tak area that produces feldspar from the pegmatite veins. Naturally, feldspar deposit in this area is both of sodium and potassium feldspars with other impurities such as quartz, muscovite, biotite, garnet and other minerals containing iron compound. In general, the feldspar are saleable, either with or without simple processing: however, the quality of feldspar can be upgraded by applying conventional concentration techniques, i.e. magnetic separation and flotation [5, 6]. Several studies were conducted to improve feldspar's specifications to meet the requirement of ceramic industries $[1,3,8$ 11]. It is suggested that the specifications of feldspar in ceramic and glass industries are $<70 \% \mathrm{SiO}_{2},>17 \%$ $\mathrm{Al}_{2} \mathrm{O}_{3},<0.1 \% \mathrm{Fe}_{2} \mathrm{O}_{3}$, with $>5 \%$ of both $\mathrm{K}_{2} \mathrm{O}$ and $\mathrm{Na}_{2} \mathrm{O}[7]$.

In this study, slime waste, fine feldspar with particle size less than 230 mesh and chemical compositions of $72.53 \% \mathrm{SiO}_{2}, 15.70 \% \mathrm{Al}_{2} \mathrm{O}_{3}, 1.56 \% \mathrm{Fe}_{2} \mathrm{O}_{3}, 0.16 \% \mathrm{TiO}_{2}, 0.40 \% \mathrm{CaO}, 0.07 \% \mathrm{MgO}, 4.87 \% \mathrm{~K}_{2} \mathrm{O}$ and $4.38 \% \mathrm{Na}_{2} \mathrm{O}$, were investigated.

\section{Concentration Process (Main Process)}

\subsection{Crushing, Grinding and Magnetic Separation Processes}

Firstly, 8" feldspar run-of-mine were transported to a hopper by wheel loader, and to a primary reciprocating grizzly feeder, in order to be screened (-1") and fed into jaw crusher. Ore particles with particle size less than 1" were passed through the slots and washed the dirt off by using spiral classifier. The overflow particles from spiral classifier were sent to the sediment pool, while the underflow particles were sent to secondary reciprocating grizzly feeder to screen the ores at $10 \mathrm{~cm}$. The ores larger than $10 \mathrm{~cm}$ were mixed with crushed ore (from jaw crusher). The ores smaller than $10 \mathrm{~cm}$ will be sent to another spiral classifier. The overflow particles will be sent to sediment pool, while the underflow particles will be mixed with the crushed ore (from jaw crusher). Then, all of ores that in the conveyor after jaw crusher will be fed into vibrating screen to classify size. The ores smaller than $3 / 4$ " were stocked in ore bin, while the ores larger than $3 / 4$ " were crushed by jaw crusher again. The flow sheet of crushing process is shown in Fig. 1. 


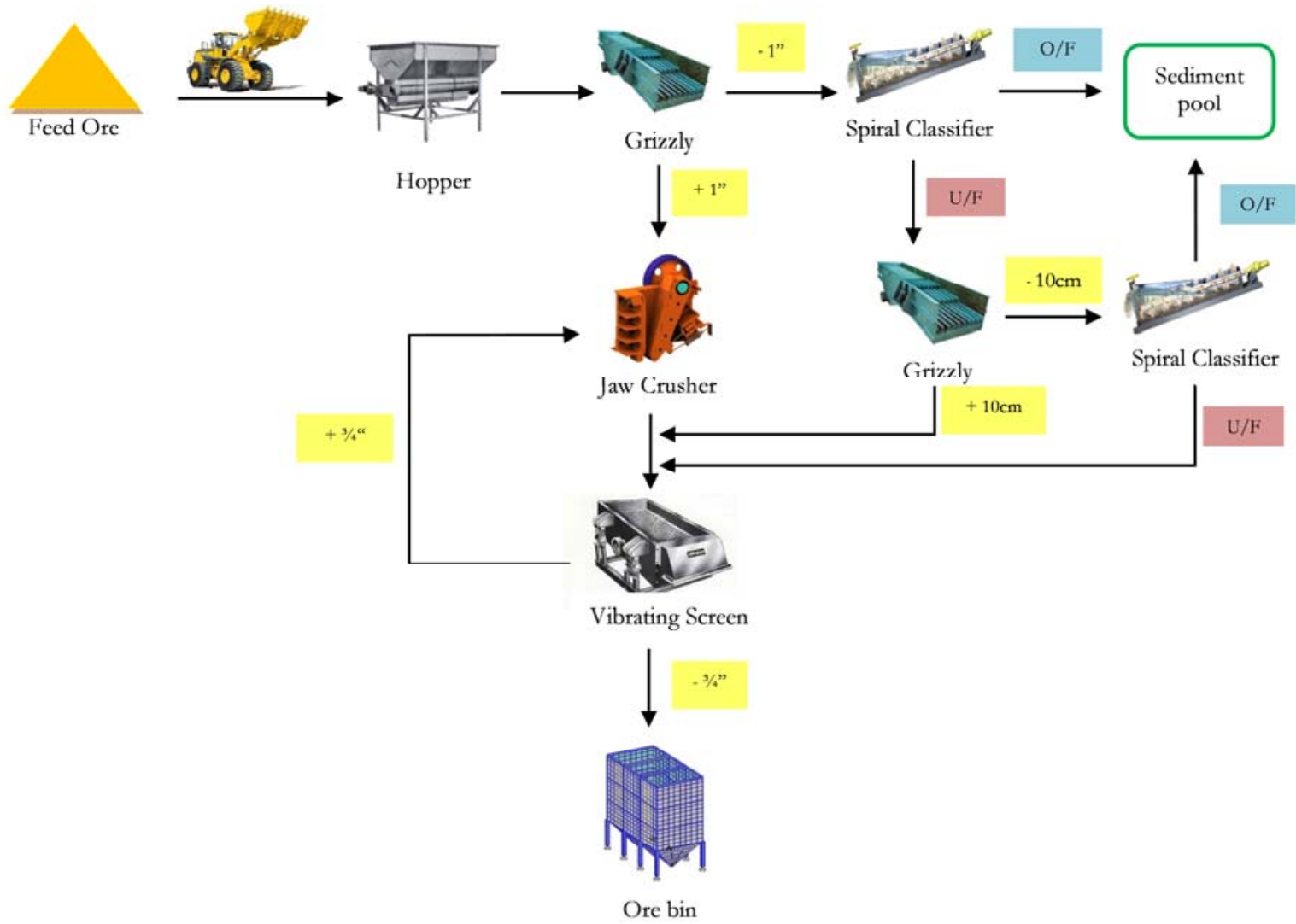

Fig.1. Crushing flow sheet of feldspar.

The coarse ores in the ore bin were fed into hopper and were conveyed to $4 \mathrm{x} 4$ and $5 \mathrm{x} 8 \mathrm{ft}$ ball mill. After that, the ores flowed into spiral classifier, the underflow particles were sent to re-grinded in the ball mill again. The overflow particles (smaller than 30 mesh) were sent to trommel to classify size of ore at 30 mesh. Ores larger than 30 mesh were fed into the ball mill again, while the ones smaller than 30 mesh were fed into cone thickener to discard slime that is smaller than 230 mesh in slime pool. Finally, the ores larger than 230 mesh were sent to sump by screw conveyor. The grinding flow sheet is shown in Fig. 2.

\section{Remark:}

- Ball mill size $4 \mathrm{x} 4 \mathrm{ft}$. has fed at the rate of 2 tons/hour; use 1 spiral classifier; cone thickener will discard slime that is smaller than 230 mesh at the rate 0.4 tons/hour.

- Ball mill size $5 \times 8 \mathrm{ft}$. has fed at the rate of 6 tons/hour; use 2 spiral classifiers; cone thickener will discard slime that is smaller than 230 mesh at the rate 1.2 tons/hour.

The slurry in the sump was pumped into 50 mesh trommel which returned oversize back to ball mill and undersize to cone classifier. Cone classifier discarded slime that is smaller than 230 mesh to the slime pool. Underflow particles were sent to attrition scrubber tank for removing surface films. After that, it passed to permanent drum magnetic separator that rejects scrap and high iron contents including mica, garnet, etc. Then, the slurry flows into 2 units of wet high intensity magnetic separator (WHIMS). Magnetic fraction flowed to spiral classifier and shaking table respectively. The non-magnetic fraction was pumped to hydrocyclone. The overflow particles were sent to sump, while the underflow particles were submitted to flotation process. The magnetic separation flow sheet is shown in Fig. 3. 


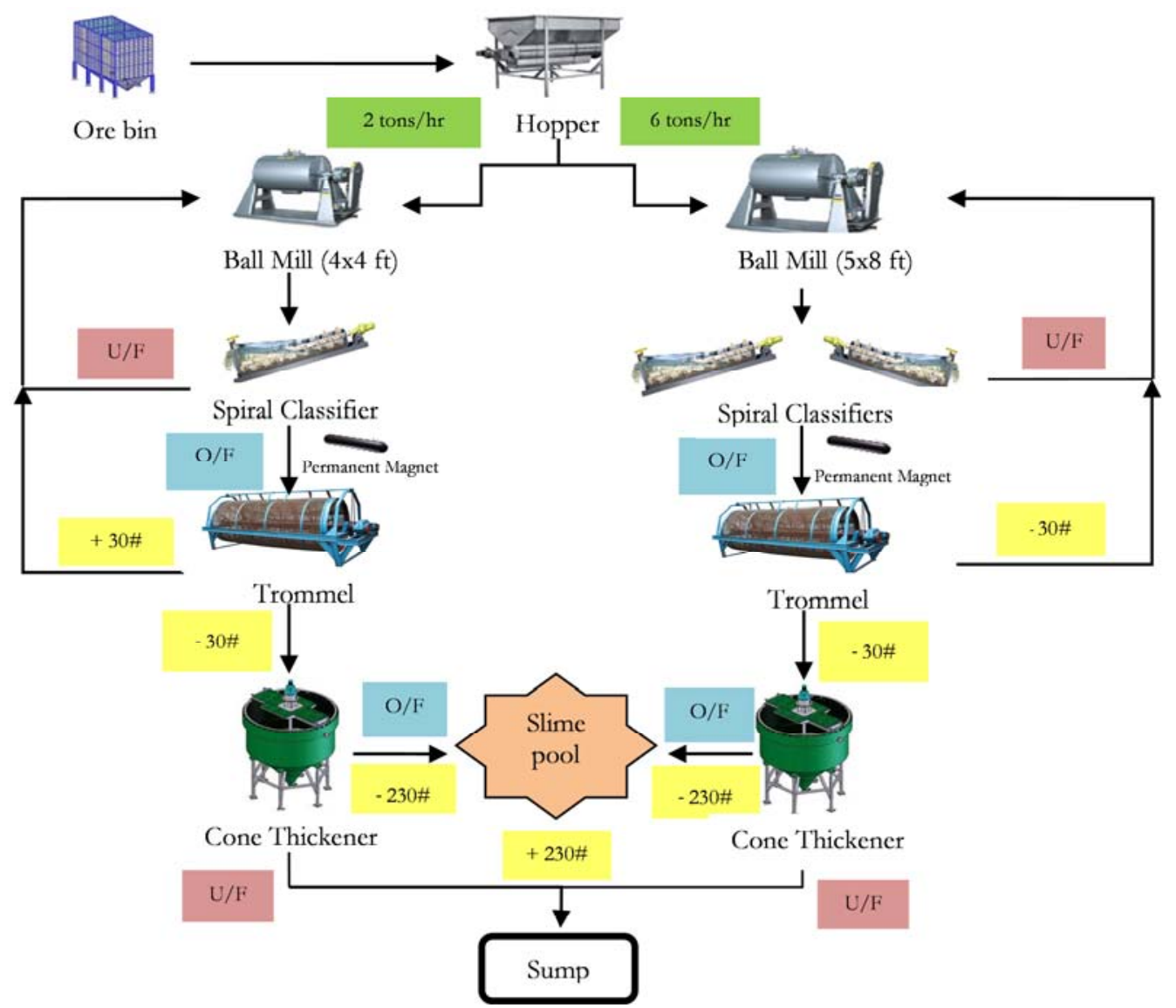

Fig.2. Grinding flow sheet of feldspar.

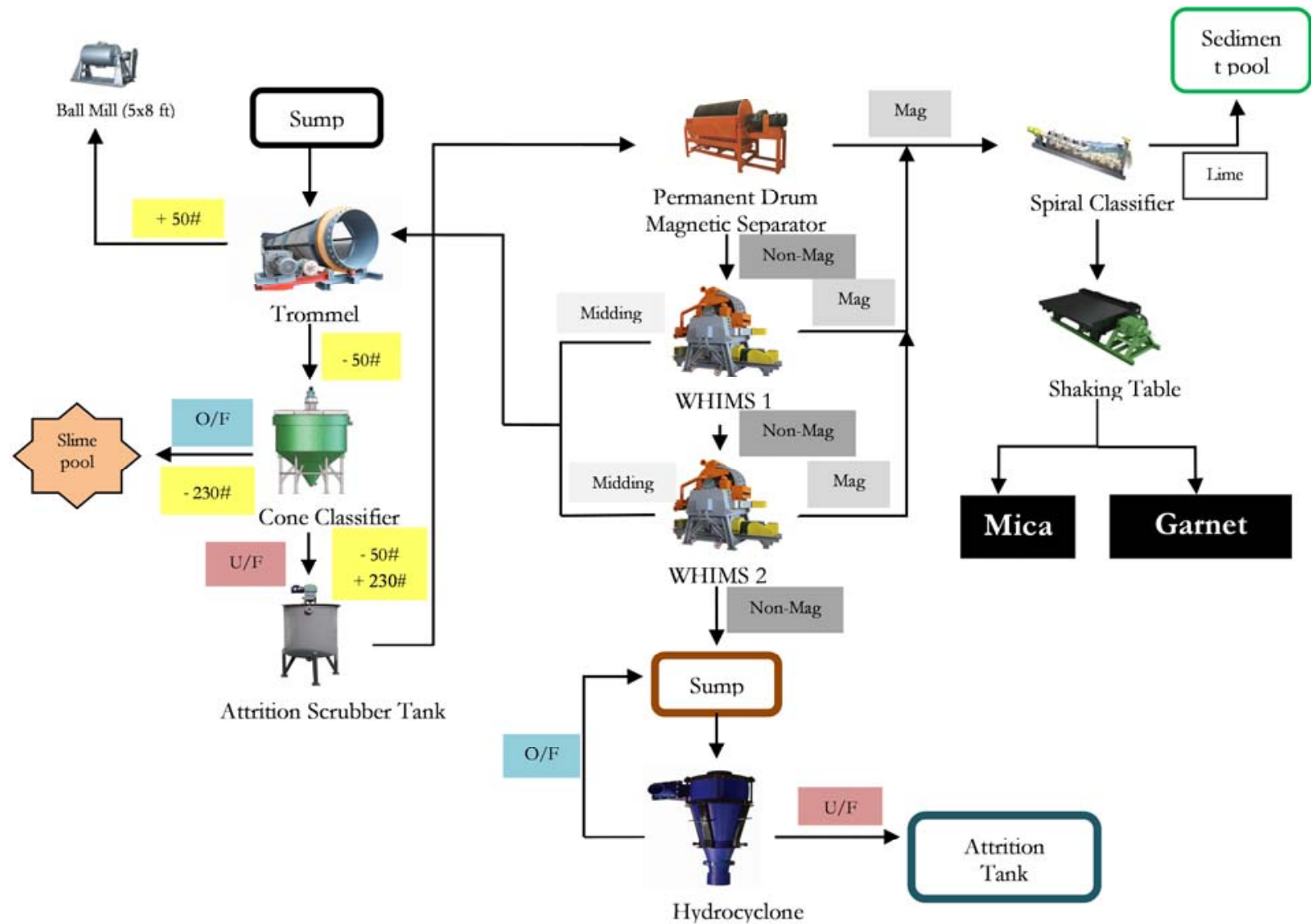

Fig. 3. Magnetic separation flow sheet of feldspar. 


\subsection{Flotation Process}

The underflow slurry from hydrocyclone flowed into the Spiral Classifier for dewatering. After that, the slurry was sent to conditioner tank for $\mathrm{pH}$ adjustment to 2 by hydrofluoric acid (HF), which is also used as a depressant. A-TD and pine oil were used as collector and frother, respectively. The latter will be added into the slurry prior feeding into the cell. The first cell (Rougher Cell), floating ore will float to the top of cell and be collected, the sinking ore from rougher cell was passed through 4 scavenger cells to recover the remaining feldspar and feed it in rougher cell. The remaining quartz flowed to fine quartz pool and underflow will flow to quartz pool as shown in Fig. 4.

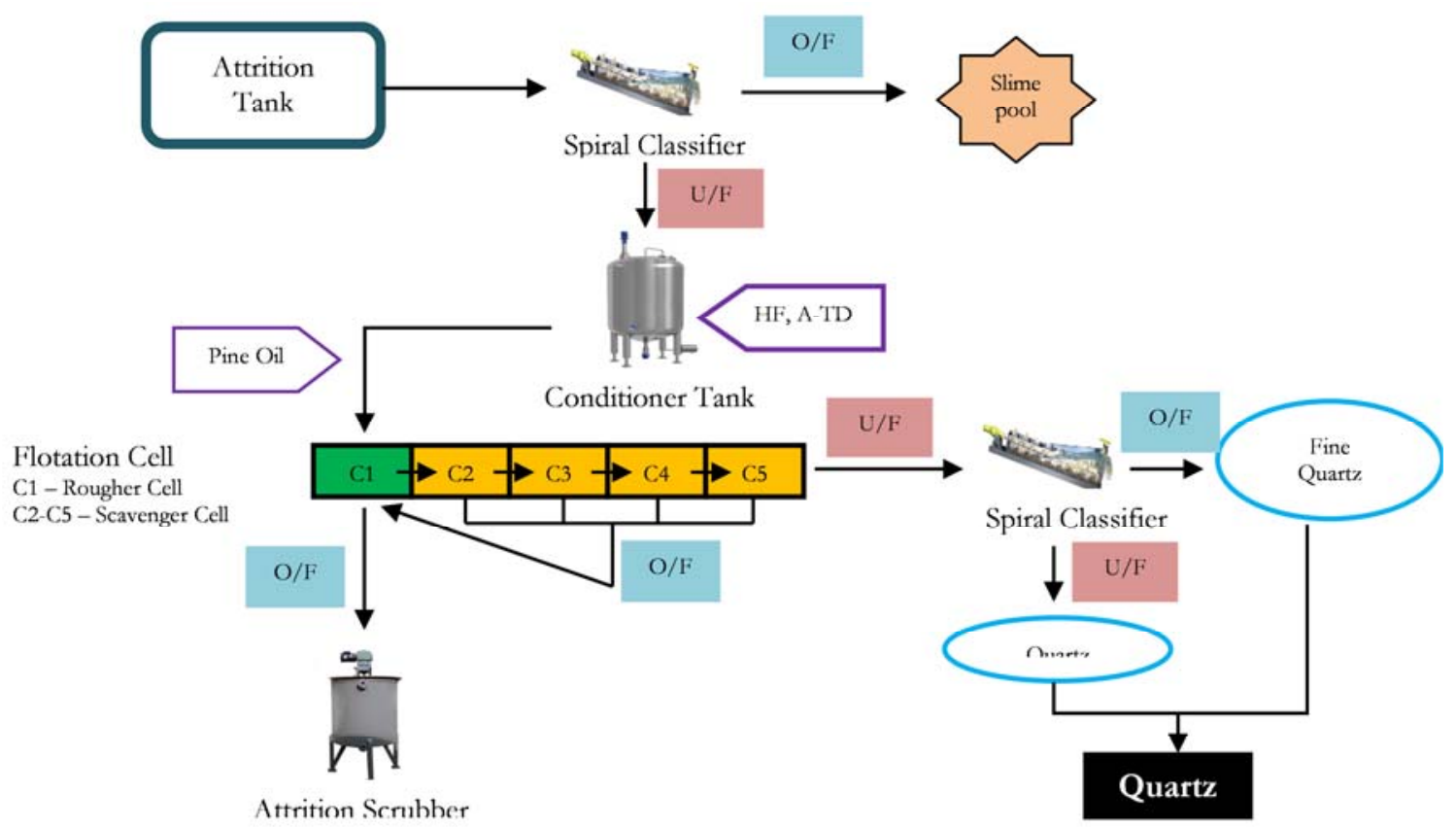

Fig. 4. Feldspar flotation flow sheet.

Figure 5 shows the floating feldspar from rougher cell flows to the 3 units of attrition scrubber tank and spiral classifier. During the process, NANSA which is the reagent for cleaning the ore surface will be added, the overflow feldspar from the last Spiral Classifier will flow to fine feldspar pool and underflow feldspar will flow to feldspar pool.

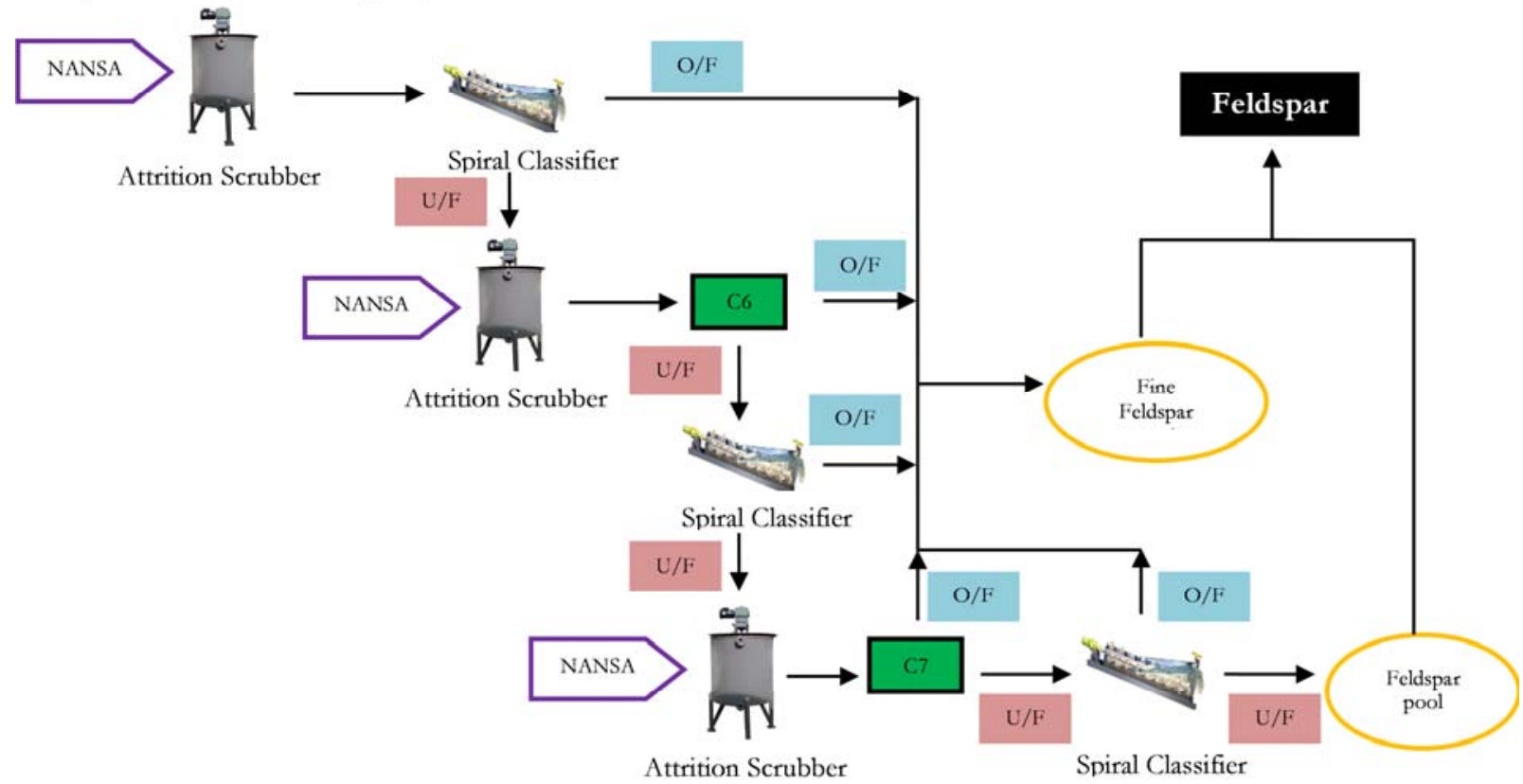

Fig. 5. Feldspar flotation circuit. 


\section{Experimental}

\subsection{Materials}

Slime waste sample used in this study was obtained from feldspar flotation plant at Attanee International Co., Ltd. It is fine feldspar which was rejected as a waste from the main processing plant. The particle size of slime is smaller than 230 mesh. The mineral compositions of this sample were investigated, in order to find an optimum condition in quartz removal flotation process and improve specification of the feldspar product. Magnetic separation will be pre-treatment prior to the flotation process in order to remove iron minerals.

\subsection{Equipment, Procedures and Reagents}

In magnetic separation process, fine feldspar (slime) from sump was pumped to the open space for drying and fed into hopper by wheel loader. After that, slime was sent into washing drum to clean mineral and scouring. Minerals and other wastes that were larger than $5 \mathrm{~mm}$, including wood and gravel etc. will be exported to the hopper waste. Ores that were smaller than $5 \mathrm{~mm}$ are sent into trommel for sizing. Minerals that are larger than 40 mesh will be screened out. While minerals smaller than 40 mesh will be sieved to pass cone thickener to separate clay and adjust percent of solid. Then, it will be sent to scrubber tank for cleaning mineral surface including separate agglomerate fine feldspar and will be sent to permanent drum magnetic separator to eliminate scrap. Next, the slime will be sent to 2 units of Wet High Intensity Magnetic Separator (WHIMS), magnetic fraction will be sent to shaking table to separate mica and garnet which are by products. The non-magnetic fraction will be pumped to hydrocyclone. Overflow particles which are smaller than 325 mesh and underflow which are larger than 325 mesh is sent to filter press for reduce humidity to less than $15 \%$ and lead ore to the next step that is flotation process as shown in Fig. 6.



Fig. 6. Magnetic separation flow sheet of slime. 


\subsection{Particle Size Distribution and Sample Characterization}

\subsubsection{Particle size distribution}

Laboratory sieve machine was used with ascending order of sieve number (100 mesh sieve at the top and 120, 140, 170, 200, 230, 270 and 325 mesh sieve respectively). Place the pan below 325 mesh sieve. Pour the slime $200 \mathrm{~g}$ into top sieve and shake for 10 minutes, then weight and record the weight of each sieve.

\subsubsection{XRD analysis}

Samples for XRD analysis were prepared by grinding the samples to minus 325 mesh and inserted into a holder with cover glass and inserted in sample changer. The samples were analyzed using an X-ray diffractometer (D8 Advance Brucker).

\subsubsection{XRF analysis}

Samples ground to minus 325 mesh were mixed with XRF wax powder and was filled in the aluminum ring. Then, press to a pellet with hydraulic press and bring the pallet to XRF machine. An X-ray fluorescence spectroscopy (S2 Ranger EDXRF) was used for the analysis.

\section{Results and Discussion}

\subsection{Particle Size Distribution and Sample Characterization of Slime}

Mean size (d50) was around $45 \mu \mathrm{m}$ (325 mesh) and the amount of $45 \mu \mathrm{m}$ particles was about $70 \%$ by mass. A plot of cumulative \% passing versus particle size $(\mu \mathrm{m})$ is shown in Fig. 7. The XRD pattern and chemical analysis, which is analyzed by XRF machine, of sample are shown in Fig. 8. and Table 1., respectively. It showed that the main gangue minerals were silicate minerals which consisted of quartz, albite, orthoclase and ferrous impurity minerals such as muscovite, biotite, mica and garnet. The contents in slime comprised mostly of $\mathrm{SiO}_{2}$ and $\mathrm{Al}_{2} \mathrm{O}_{3}$ and amounts to about $90 \%$.

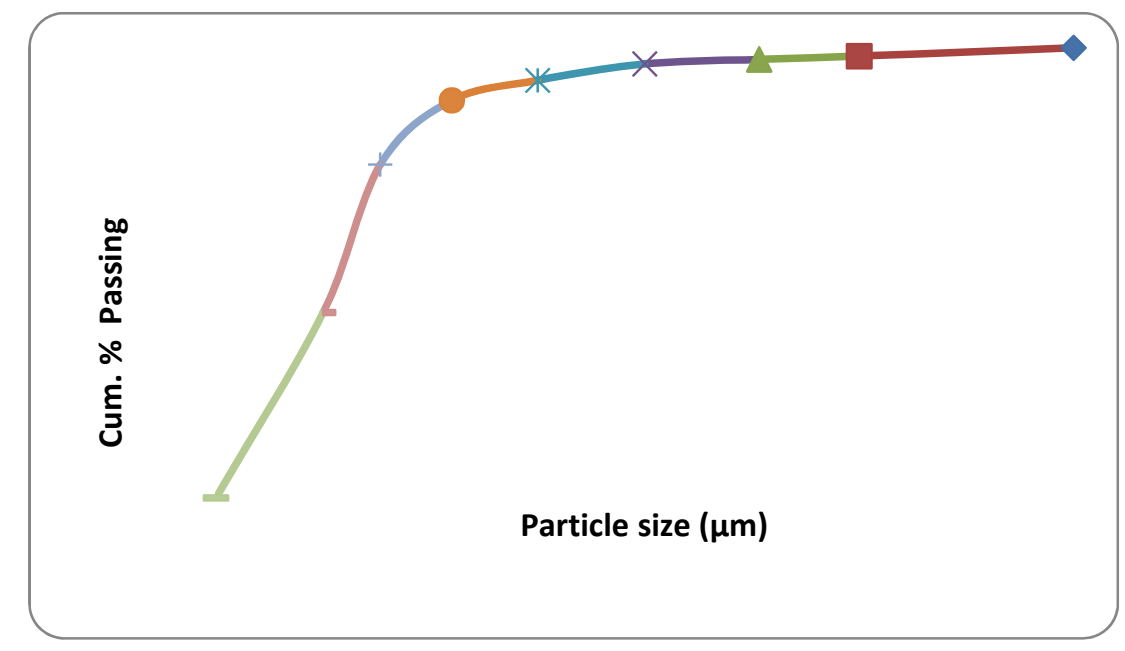

Fig. 7. Cumulative $\%$ passing of slime sample versus particle size $(\mu \mathrm{m})$. 


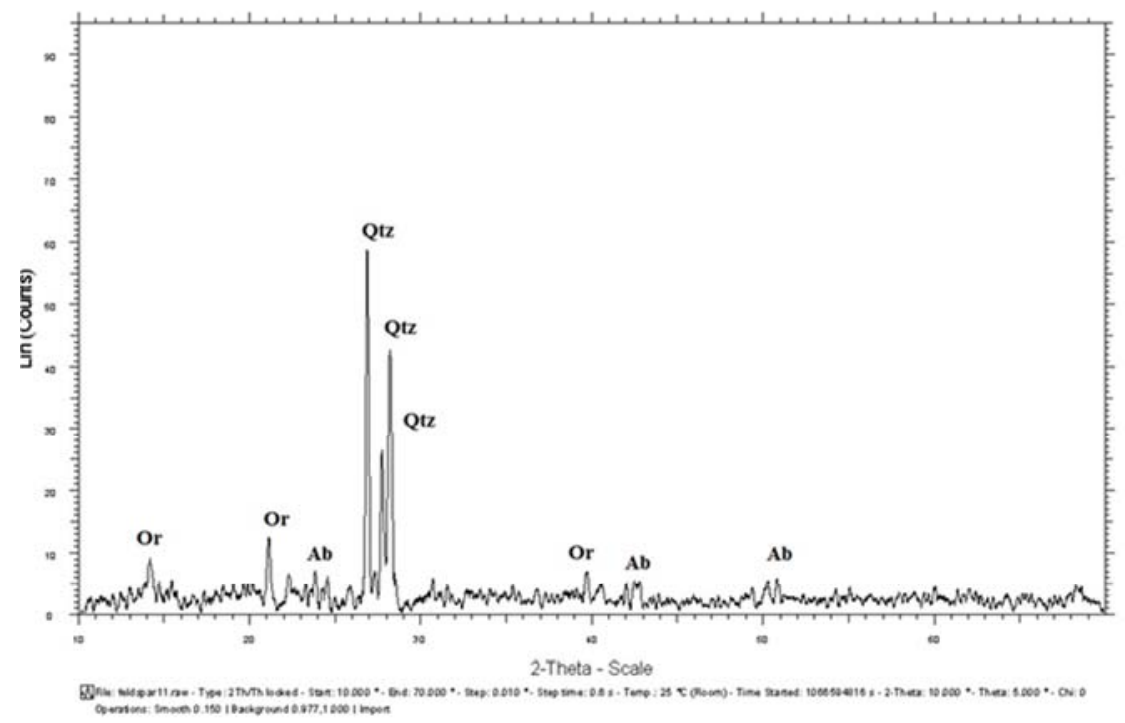

Fig. 8. XRD pattern on slime sample.

Table 1. Chemical composition analysis of the slime sample.

\begin{tabular}{cccccccc}
\hline \multicolumn{2}{l}{ Chemical composition (\%) } & \multicolumn{1}{l}{} \\
\hline $\mathrm{SiO}_{2}$ & $\mathrm{Al}_{2} \mathrm{O}_{3}$ & $\mathrm{Fe}_{2} \mathrm{O}_{3}$ & $\mathrm{TiO}_{2}$ & $\mathrm{CaO}$ & $\mathrm{MgO}$ & $\mathrm{K}_{2} \mathrm{O}$ & $\mathrm{Na}_{2} \mathrm{O}$ \\
72.53 & 15.70 & 1.56 & 0.16 & 0.40 & 0.07 & 4.87 & 4.38 \\
\hline
\end{tabular}

\subsection{Magnetic Separation Process of Slime}

After magnetic separation process, the slime concentrate consisted the most of albite, orthoclase and quartz with XRF analysis as shown in Table 2. It showed that the slime has very high grading of $\mathrm{SiO}_{2}$ that is remain unsuitable for commercial specification at a yield of slime approximately $35 \%$. Thus, this slime could be upgraded by flotation technique.

Table 2. Chemical composition analysis of the slime sample after magnetic separation process.

\begin{tabular}{llllllll}
\hline \multicolumn{2}{l}{ Chemical composition (\%) } & & & & & \\
\hline $\mathrm{SiO}_{2}$ & $\mathrm{Al}_{2} \mathrm{O}_{3}$ & $\mathrm{Fe}_{2} \mathrm{O}_{3}$ & $\mathrm{TiO}_{2}$ & $\mathrm{CaO}$ & $\mathrm{MgO}$ & $\mathrm{K}_{2} \mathrm{O}$ & $\mathrm{Na} 2 \mathrm{O}$ \\
74.43 & 15.15 & 0.12 & 0.04 & 0.43 & 0.01 & 4.73 & 4.75 \\
\hline
\end{tabular}

\subsection{Froth Flotation}

Since feldspar can be separated from quartz-feldspar mixture by froth flotation. At the best selectivity which is acidic solutions with amine as collector and hydrofluoric acid as a modifier [12]. Upgrading slime by froth flotation in order to separate feldspar and quartz is elaborated in varied $\mathrm{pH}$ conditions and quantity of collector. In acid condition, floated product rather sticks with bubble. At $\mathrm{pH} 2$ color of floated product is orange and sink product is white. In base condition, floated product is less stick with bubble. At $\mathrm{pH} 10$, color of floating product and sinking product is lightly orange. The results showed that during $\mathrm{pH} 3$ and $\mathrm{pH} 12$, quartz and feldspar cannot be separated, while atpH 2, quartz and feldspar can be separated. Because the zero point of charge (ZPC) of quartz is at $\mathrm{pH} 2$ and feldsparstill remains negative charge at $\mathrm{pH}$ 2 as shown in Fig. 9 [13]. Thus, at this $\mathrm{pH}$ is optimum condition for separation. Amount of collector can affect the separation. The optimum amount of collector is $140-180 \mathrm{~mL}$ as shown in Table. 3. And the chemical component of floated product and sink product is shown in Table 4. That is suitable for ceramic industry. 
Table 3. The result of flotation test at $\mathrm{pH} 2$.

\begin{tabular}{ccccc}
\hline \multicolumn{5}{c}{$\mathrm{pH} 2$ (used HF around 400 mL) } \\
\hline A-TD (mL) & \% Floated & $\%$ Sink & $\%$ Loss & Ratio (F/S) \\
20 & 26.3 & 69.0 & 4.7 & 0.38 \\
40 & 35.7 & 58.1 & 6.2 & 0.61 \\
60 & 37.7 & 56.8 & 5.5 & 0.66 \\
80 & 38.1 & 56.4 & 5.5 & 0.68 \\
100 & 62.9 & 34.4 & 3.3 & 1.81 \\
120 & 64.3 & 31.3 & 4.4 & 2.05 \\
140 & 69.7 & 24.8 & 5.5 & 2.81 \\
160 & 69.2 & 24.9 & 5.9 & 2.78 \\
180 & 69.2 & 24.4 & 6.4 & 2.84 \\
200 & 71.2 & 23.7 & 5.1 & 3.00 \\
\hline
\end{tabular}

Table 4. Chemical component analysis of floating and sinking product of slime sample in test at pH 2 with 60, 100, 140 and $180 \mathrm{~mL}$. of A-TD.

\begin{tabular}{ccccccccc}
\hline \multicolumn{7}{c}{ Chemical component $(\%)$ at $\mathrm{pH} 2$} \\
\hline A-TD (mL) & $\mathrm{SiO}_{2}$ & $\mathrm{Al}_{2} \mathrm{O}_{3}$ & \multicolumn{7}{c}{$\mathrm{Fe}_{2} \mathrm{O}_{3}$} & $\mathrm{TiO}_{2}$ & $\mathrm{CaO}$ & $\mathrm{MgO}$ & $\mathrm{K}_{2} \mathrm{O}$ & $\mathrm{Na}_{2} \mathrm{O}$ \\
& & \multicolumn{7}{c}{ Floated product } \\
60 & 67.18 & 18.86 & 0.12 & 0.02 & 0.48 & 0.008 & 7.43 & 5.90 \\
100 & 67.38 & 18.69 & 0.12 & 0.02 & 0.48 & 0.008 & 7.41 & 5.90 \\
140 & 67.82 & 18.54 & 0.14 & 0.03 & 0.52 & 0.006 & 6.88 & 6.07 \\
180 & 67.86 & 18.54 & 0.19 & 0.02 & 0.51 & 0.008 & 6.77 & 6.10 \\
& & & Sink product & & & & \\
60 & 90.91 & 6.86 & 0.16 & 0.02 & 0.42 & 0.013 & 1.37 & 0.25 \\
100 & 90.83 & 7.10 & 0.17 & 0.05 & 0.90 & 0.013 & 0.61 & 0.33 \\
140 & 99.40 & 0.23 & 0.13 & 0.01 & 0.14 & 0.009 & 0.06 & 0.02 \\
& 99.36 & 0.30 & 0.13 & 0.01 & 0.09 & 0.008 & 0.08 & 0.02 \\
\hline
\end{tabular}

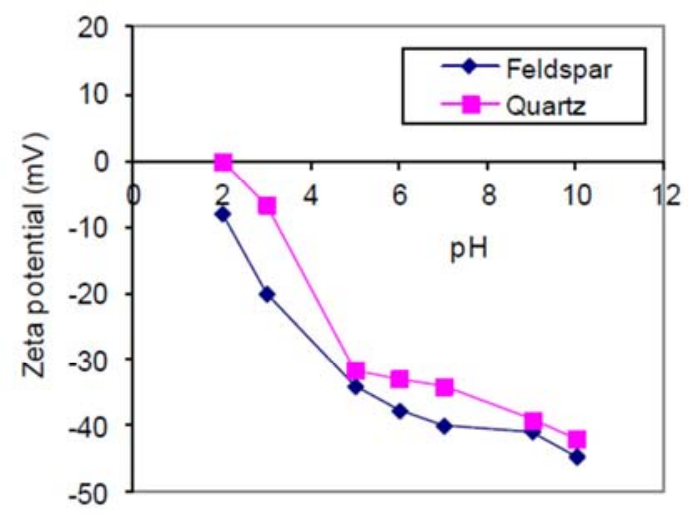

Fig. 9. Zeta-potential of quartz and feldspar.

\section{Conclusions}

The study of recovery slime waste from feldspar flotation plant, after magnetic separation process and froth flotation process, experimental study indicated that product specification could be upgraded to ceramic industry. It is suggested that Hydrofluoric acid (HF) should be used as a pH modifier, and adjusted to $\mathrm{pH} 2$ While, A-TD is a collector. Approximately $140,000 \mathrm{~mL}$ per ton feed led to yield of $69.7 \%$, and provided feldspar concentrates assaying $67.82 \% \mathrm{SiO}_{2}, 18.54 \% \mathrm{Al}_{2} \mathrm{O}_{3}, 0.14 \% \mathrm{Fe}_{2} \mathrm{O}_{3}, 0.03 \% \mathrm{TiO}_{2}, 0.52 \% \mathrm{CaO}, 0.006 \%$ $\mathrm{MgO}, 6.88 \% \mathrm{~K}_{2} \mathrm{O}$ and $6.07 \% \mathrm{Na}_{2} \mathrm{O}$. 


\section{Acknowledgements}

The authors would like to express gratitude and appreciation towards Attanee International Co., Ltd., Laboratory of Sustainable Resource Engineering, Graduate School of Engineering, Hokkaido University, Japan, and Graduate School of Engineering, Chulalongkorn University for useful information and assistance in this research.

\section{References}

[1] M. E. Gaied, and W. Gallala, "Beneficiation of feldspar ore for application in the ceramic industry: Influence of composition on the physical characteristics," Arabian Journal of Chemistry, vol.8, pp. 186190, 2015.

[2] V. Bozkurt, Y. Ucbas, S. Koca, and H. Ipek, "Recovery of feldspar from trachyte by flotation," Minerals Engineering, vol. 19, pp. 1216-1217, 2006.

[3] C. Karaguzel, I. Gulgonul, C. Demir, M. Cinar, and M. S. Celik, "Concentration of K-feldspar from a pegmatitic feldspar ore by flotation," International journal of mineral processing, vol. 81, pp. 122-132, 2006.

[4] S. Bulatovic, "Beneficiation of feldspar ore," in Handbook of Flotation Reagents: Chemistry, Theory and Practice, $1^{\text {st }}$ ed. Elsevier science, vol. 2, pp. 107-119, 2010.

[5] M. S. Celik, R. H. Eren, G. Uztek, C. Gurcuoglu, and M. Z. Dogan, "Beneficiation of nepheline syenite by magnetic separation and flotation techniques," in Proceedings of the sth $^{\text {th }}$ Balkan Mineral Processing Conference, Belgrade, 1999, pp. 105-110.

[6] Z. Sekulic, N. Canic, Z. Bartulovic, and A. Dakovic, "Application of different collectors in the flotation concentration of feldspar, mica and quartz sand," Minerals Engineering, vol. 17, pp. 77-80, 2004.

[7] C. Patamasut, "Feldspar flotation for ceramic industry," in Proceedings the 3rd Conference on Mining, Pattaya, 1989, pp. 463-471.

[8] I. Bayraktar, S. Ersayin, and O. Y. Gulsoy, "Upgrading titanium bearing Na-feldspar by flotation using sulphonates, succinamate and soaps of vegetable oils," Minerals Engineering, vol. 1, no. 12, pp. 13631374, 1997.

[9] E. C. Orhan, and I. Bayraktar, "Amine-oleate interactions in feldspar flotation," Minerals Engineering, vol. 19, pp. 48-55, 2006.

[10] I. Gulgonul, C. Karaguzel, and M. S. Celik, "Surface vs. bulk analyses of various feldspars and their significance to flotation," International journal of mineral processing, vol. 86, pp. 68-74, 2008.

[11] S. Somsak, B. Thitisak, and M. Pinyo, "Upgrading feldspar by WHIMS and flotation techniques," Engineering Journal, vol. 19, no.4, pp. 83-92, 2015.

[12] M. S. Elsalmawy, Y. Nakahiro, and T. Wakamatsu, "The role of alkaline earth cations in flotation separation of quartz from feldspar," Minerals Engineering, vol. 6, no. 12, pp. 1231-1243, 1993.

[13] H. H. Buckenham, and J. Rogers, "Flotation of quartz and feldspar by dodecylamine," Tran. Instn. Min. Metall., vol. 64, pp. 11-30, 1954. 